\title{
TELECOMMUNICATIONS IN THE NEW WORLD
}

\author{
FRANCIS COLT DE WOLF†
}

THE international regulation of telecommunications ${ }^{1}$ began in 1865 , twenty years after the invention of the electric telegraph, with the establishment of the International Telegraph Union. Similar organizations subsequently established (including notably the Universal Postal Union) ${ }^{2}$ adopted the basic pattern of the Telegraph Union: a basic treaty or convention which is concluded at a plenipotentiary conference, regulations annexed to the convention which are amended at regular intervals (usually at five-year periods at an administrative conference), and a permanent bureau placed under the aegis of the Swiss Government and having its seat at Bern. The Bureau acts as a secretariat for the Union, issues its publications, cooperates in the program of international conferences with the inviting government, and serves as a medium of correspondence between the members of the Union. It should be emphasized that the Telegraph Union did not have administrative bodies sitting permanently with powers to act between conferences.

At the time of its creation, there was no corresponding political union in Europe or elsewhere in the world. The Concert of Europe, i.e., the Great Powers, had no formal organization and only met when a crisis threatened, or as a peace conference after a war. ${ }^{3}$ The Telegraph Union and its sister organization, the Postal Union, thus set a pattern of international organization well in advance of a similar political organization. Their exemplary influence is traceable even upon the League of Nations, as the League presumably borrowed the idea of its secretariat from the bureaus set up at Bern " and also followed

$\dagger$ Assistant to the Solicitor, Department of State, Washington, 1922-31; member of Secretariat of League of Nations, Geneva, 1931-4; lecturer on International Law, Gcorge Washington University, Washington, 1942-present; Divisional Assistant, Division of International Communications, Department of State, Washington, August, 1938; Alternate Member, Board of War Communications, 1912-present; Chief, Telecommunications Division, January 15, 1944.

1. The term "telecommunications," however, was first officially adopted in 1932 in the Annex to the Madrid International Telecommunication Convention, 49 Srax. 2441 (1936), where it is defined as, "Any telegraph or telephone communication of signs, signals, writings, images, and sounds of any nature, by wire, radio, or other systems or processes of electric or visual (semaphore) signaling."

2. See L'Unton télÉgraphioue INTERNattonale, 1865-1915 (1915) published by the Bureau of the International Telecommunication Union at Bern.

3. Hershey, The Essentials of International Public Law and Organization (1927) 241.

4. These organizations are in the order of their creation: The International Telccommunications Union-previously the International Telegraph Union, established in 1865; the Universal Postal Union, 1874; the Union for the Protection of Industrial Proparty, 
their example in choosing Switzerland as a permanent home. But there the analogy ceases, for the League of Nations went far beyond the simple structure of the previous administrative unions.

But while world political organization progressed and the physical art of communications matured, the industry's international organization remained relatively stagnant. When established, the International Telegraph union was primarily concerned with wire telegraphy on the Continent of Europe, and the United States was not even a member. Since then the emergence of radio has made the organization truly global; yet, except for the substitution of an all-inclusive Telecommunications Commission ${ }^{5}$ for the previous Telegraphic Union, no fundamental administrative change has been made since 1865. Even the administrative consolidation of radio and telegraph was not accomplished until $1932 .{ }^{6}$

The first International Radio Conference took place in Berlin in 1903. The principles embodied in the final protocol of this Conference, finally put into effect in 1912, have remained the basic law of international radio regulations, notably, the rules that coastal stations are obliged to exchange telegrams with ship stations without regard to the system employed; that distress calls have priority; that services must be organized in such a way as to avoid interference with other stations; and that military and naval services are exempt from the provisions of the regulations except with regard to distress calls and interference. The basic principles of rate regulations in this field of communications were also adopted.?

World War I interrupted the process of regulating radio waves; not until $1927,{ }^{8}$ at an international radiotelegraph conference in Washington, did the nations of the world adopt the first table of allocations which has become the guide for all international policing of the radio spectrum.

1883; the Union for the Protection of Literary and Artistic Works, 1886; and the International Union of Railroads. These Unions, of which the first two are practically universal, and the third and fourth of which represent interests of a character equally universal, have a permanent bureau. By the terms of the conventions which govern them, these bureaus are placed under the supervision of the Swiss Government. (See Dep't of State, Telecommunications Division, Ser. No. 186, General Information Doc. No. 9.)

5. Telecommunications Convention Between the United States of America and Other Powers. Treaty Ser. No. 867 (1932).

6. Ibid.

7. Final Protocol of the Preliminary Conference between Great Britain, AustriaHungary, France, Germany, Italy, Spain, Russia, and the United States, respecting Wireless Telegraphy. Signed at Berlin, August 13, 1903. See 97 British aNd Foreign STate PAPERS (1908) 467.

8. Radiotelegraph Convention and General Regulations Between the United States and Other Powers. U.S. TReaty Ser. No. 767 (1927). 
Five years later, in 1932, in Madrid, ${ }^{\circ}$ the first Telecommunications Conference administratively consolidated radio, telephone and telegraph, and established a uniform convention to which the United States was willing to subscribe. As in former days, however, the United States abstained from becoming a party to the Telegraph Regulations on the ground that in this country telegraphy was largely carried on by private companies. In Cairo, in $1938,{ }^{10}$ at the last Telecommunications Conference before the recent war, the regulations annexed to the Madrid Convention were amended without changing the convention itself. These are the regulations in effect today.

In the five-year period which elapsed between the Madrid and Cairo Conferences, increased demands for additional radio frequencies by the mobile, fixed and broadcasting services called for more restrictive rules to make the most economical use possible of existing facilities, as well as for a new consideration of the table of frequencies adopted at Madrid.

Some of the more important decisions of the Cairo Radio Conference included the following:

1. Adoption of a plan for radio channels for the world's seven main intercontinental air routes, including calling and safety service channels.

2. Widening of the high frequency broadcast bands to a total of 300 kilocycles and the adoption of special bands for tropical regions for regional use.

3. The limitation of the use of spark sets to three channels and the outlawing of spark sets except below 300 watts output.

4. Improved tolerance and bandwidth tables.

5. The extension of the allocation table to 200 megacycles for the European region. Other regions were given the right to effect their own arrangements above 30 megacycles.

6. Establishment of further restrictions on the use of 500 kilocycles frequency for traffic.

7. Modernization of regulations relative to the maritime and aeronautical services. ${ }^{11}$

The Cairo Conference was to be followed by an administrative conference in Rome in 1942, but World War II intervened. War resulted in tremendous expansion of the use of radio, especially in aviation and

9. Telecommunication Convention Between the United States of Ameriea and Other Powers. U. S. Treaty Ser. No. 867 (1932).

10. General Radio Regulations (Cairo Revision, 1938) and Final Radio Protocol (Cairo Revision, 1938) Annexed to the Telecommunication Convention (MIadrid, 1932) Between the United States of America and Other Powers. U. S. Treaty Ser. No. 948 (1938).

11. See de Wolf, The Cairo Telecommunication Conferences (1938) 32 A:s. J. Irit. L. 562. 
short wave broadcasting, making it imperative that a new world conference be called as soon as possible, not only to amend the regulations appended to the Madrid Convention but also to change the Convention itself.

In order fully to understand the need for thoroughgoing modification, a brief description of the Telecommunications Union and its various organs (which in 1932 succeeded the earlier Telegraph Union) will be helpful. At the Madrid Radio-telegraph Conference in 1932 the inter* national organization of telegraphs, telephones and radio was unified by the creation of the present International Telecommunication Union, to which practically all countries in the world belong. The basic instrument constituting the Union is a Convention to which are appended three separate sets of regulations governing telegraphy, telephony and radio communications. The Union is composed of the following organizations:

1. Plenipotentiary conferences which meet only when the Convention which embodies the fundamental statutes of the Union is under revision. (The last conference took place at Madrid in 1932.)

2. International telegraph, telephone, and radio administrative conferences which review the regulations.

3. International consultative committees: the Telegraph Committee (C.C.I.T.), the Radiocommunication Committee (C.C.I.R.), and the Telephone Committee (C.C.I.F.). These consultative committees deal mainly with technical questions and except for the C.C.I.F., have only advisory powers.

4. A bureau or permanent secretariat, which is called the Bureau of the International Telecommunication Union, has its seat in Bern, and is under the aegis of the Swiss Government. ${ }^{12}$

From the foregoing it should be clear that the International Telecommunication Union, unlike the new Provisional International Civil Aviation Organization (PICAO) and the United Nations, has no bodies which can effectively dispose of problems that may arise in the intervals between conferences. The committees on telegraphy and radio communications are purely consultative bodies which advise the next administrative conferences on technical matters, and can take no action of their own in the interim. This is not true of the C.C.I.F. which has a permanent secretariat and which effectively correlates the activities of the various telephone administrations in Europe.

It is obviously desirable to bring about a close relation between the United Nations and the International Telecommunication Union. Articles 57 and 63 of the Charter of the United Nations provide as follows:

12. Mance, INTERnationat Telecomaunications (1944) 2. 
"Article 57.

"1. The various specialized agencies, established by intergovernmental agreement and having wide international responsibilities, as defined in their basic instruments, in economic, social, cultural, educational, health, and related fields, shall be brought into relationship with the United Nations in accordance with the provisions of Article 63.

"2. Such agencies thus brought into relationship with the United Nations are hereinafter referred to as specialized agencies."

"Article 63.

"1. The Economic and Social Council may enter into agreements with any of the agencies referred to in Article 57, defining the terms on which the agency concerned shall be brought into relationship with the United Nations. Such agreements shall be subject to approval by the General Assembly.

"2. It may coordinate the activities of the specialized agencies through consultation with and recommendations to such agencies and through recommendations to the General Assembly and to the Members of the United Nations." 13

At its meeting in New York in May, $1946,{ }^{14}$ the Temporary Transport and Communications Commission of the United Nations considered inter alia the problem of the relationship between the United Nations and certain specialized agencies, including the International Telecommunication Union. The following is quoted from the Commission's report to the Economic and Social Council:

"(c) Specialized Agencies.

"There should be a permanent world-wide agency in each of the four world-wide fields mentioned above. In working towards the development of such agencies, as much use as possible should be" made of existing bodies. For the present, only existing agencies should be considered.

"In three fields there are existing world inter-governmental organizations which, with some possible revision, appear on preliminary examination to be suitable for relationship to the Economic and Social Council. This refers to the Universal Postal Union, the International Telecommunication Union, and the Provisional International Civil Aviation Organization. (To be superseded by the International Civil Aviation Organization). . . .

"As concerns the ITU it is agreed that its organization is laclsing any permanent governing body. Its charter should be somewhat modified to enable the ITU to be brought into relation with the United Nations. The Commission hopes a conference will be con-

13. U. S. TREATY SER. No. 993 (1946).

11. United Nations, Economic and Social Council, Doc. E/42 (1946). 
vened soon to that effect. The statutory difficulties of convening such a conference are referred to in Section 10 of this Report."

The Economic and Social Council, at a meeting in New York in June, 1946, approved a resolution on the report of the Temporary Transport and Communications Commission which contains the following inter alia:

"6. The Council expresses the hope that a world conference in the field of telecommunications shall be convened as soon as pos* sible to review the organization of the International Telecommunication Union and its radio regulations and to enable the International Telecommunication Union to be brought into relationship with the United Nations.

"7. The Secretary-General is directed to convene, as soon as possible, a meeting of telecommunications experts designated by the governments of all the countries Members of the United Nations which might desire to participate in such a meeting, with a view to drafting propositions to be submitted by the respective administrations to the Telecommunications Conference with respect to bringing the International Telecommunications Union into relationship with the United Nations." 15

Meanwhile, interdepartmental groups in the United States, with the help of American telecommunication companies, have for the last two years been working on the proposals to be presented by the American Delegation at the next World Telecommunication Conference, which it is hoped will take place in the spring of 1947 . These proposals, ${ }^{10}$

15. United Nations, Economic and Social Council, Doc. E/58/Rev. 1 (1946).

16. "Article 2 of the American Delegation's proposed constitution reads as follows: "Structure of the Union

"§ 1. Under the authority of the International Telecommunications Union there shall be:

"(1) Boards and Committees to deal with specific phases of international telecommunication activities, the composition, duties and functions of which shall be defined in the Regulations annexed to this Convention.

"(2) An International Telecommunications Administrative Council to be composed of the Chairman of each Board and Committee provided for in paragraph 1 (1). The Administrative Council shall elect its Chairman. The Administrative Council, in addition to performing any other specific duties assigned to it by the International Telecommunications Conference, shall (a) appoint the Secretary of the Union and supervise his activities, (b) direct the administrative functions of the Union, (c) approve the annual budget submitted by the Secretary, (d) audit the accounts prepared by the Secretary and transmit them to the succeeding International Telecommunications Conference and (e) perform such other administrative duties as may be necessary to insure the proper functioning of the Union.

Union, who shall:

"(3) A secretariat serving under the direction of the Secretary of the

"a. Maintain the official master list compiled from data filed

with him for the purpose by Boards and Committees of the Union. 
which include revisions of the Madrid Radiotelegraph Conference and of the Cairo Radio Regulations, contemplate a greatly strengthened union with permanent bodies to run its own affairs in the interim between conferences. The Union contemplated by the American Proposal would employ boards and committees to deal with specific phases of international telecommunications, one of the most important of which would be a Central Frequency Registration Board composed of five regular and two alternate members, each from a different nation and of recognized qualifications. This CFRB would undertake to coordinate on a scientific basis the registration of frequencies, which now is done merely as a recording activity by the Bern Bureau.

$\downarrow$. While the CFRB would act only in an advisory capacity, it would provide a forum for the settlement of international disputes in the field

"b. Maintain complete records of and publish the International and Regional Telecommunications arrangements.

"c. Perform all other secretarial functions of the Union including those of its Boards and Committees.

"d. Carry on work preparatory to, and following conferences of, the International Telecommunications Union.

"e. Provide, in cooperation with the organizing government, the secretariat of conferences of the Union as well as, when so requestcd or when so provided by these Regulations, the secretariat of meetings of boards and committees appointed by the Union or placed under its auspices.

"f. Prepare and publish the official service documents of the Union as prescribed by the Regulations and such other documents as the Administrative Council may direct.

"g. As directed by the Union, gather data regarding telecommunications facilities throughout the world, both international and national, and publish them in suitable form.

"h. Publish periodically, on the basis of information put at his disposal or which he may gather, a journal of general information concerning telecommunications.

"i. Prepare an annual report of his official activities which, after approval by the Administrative Council, shall be communicated through the Administrative Council to all members of the Union. trative Council.

"j. Prepare an annual budget for approval by the Adminis.

"k. Prepare an operating account which shall be submitted to the Administrative Council annually and also immediately preceding each International Telecommunications Conference. These accounts, after approval by the Administrative Council, shall be submitted by it to the plenipotentiary or administrative conference for esamination and final approval.

"1. Arrange when requested (Art. 8 Section 4) for limited administrative conferences including the provision of the secretariat.

"m. Perform such other duties as may be delegated to him by the Convention, Regulations or by Conferences of the International Telecommunications Union." 
of frequency registration and an agency for the submission of expert advice to registering governments.

A further important revision looking toward speedy solution of international problems in the telecommunications field is proposed. This is, in addition to the regularly accepted plenipotentiary and administrative conferences, a new type of conference known as an Administrative Conference with limited agenda, sometimes referred to in official circles as a "quickie."

Under the United States proposal, international conferences could be set up with as little as three months' notice and would consider only a few current and urgent problems, thus avoiding the long delays heretofore incident to regular conferences. Under present international procedure, problems that arise must await world conferences, sometimes four years or more. ${ }^{17}$

Telecommunications are inextricably linked to our everyday life; daily newspapers would be local gossip sheets without the telephone, telegraph (both radio and wire), facsimile, telephoto, and broadcasting. Between the morning, noon and evening papers, both standard and short wave broadcasting keep us informed of what the world is doing. Trains are controlled by telegraph and telephone, and soon will be equipped with radiotelephone. Safety of life in the air and at sea would be impossible without radiotelephone, radiotelegraph, and other radio aids to navigation, including radar.

Because telecommunications are so closely linked with transportation by sea, air, and land, it is important that its regulations mesh with those governing aviation, shipping, and land transportation. Therefore, the administrative organs in these various fields must be designed and located so that their officials may have day-to-day contacts. It is most desirable that there exist an organ which can reconcile any divergence which may arise in matters of common concern, i.e., radio frequency allocations, terminology, and regulation of common safety devices. The Economic and Social Council and the Transport and Communications Commission of the United Nations seem appropriate bodies for this task.

What accomplishments may be expected in the immediate future? (1) A minimum of interference brought about by an expanded radio spectrum with transmitters and receivers built with a maximum of precision and accuracy; (2) the use of landlines and cables as secondary means of communications to relieve the congestion in certain parts of the spectrum; (3) the establishment of an international frequency board which will, in advance, point out the possibility of interference in any suggested registration with the Bern Bureau (this step does not appear so bold when we consider what the Federal Communications

17. See (1946) 30 Broadcasting 97. 
Commission does for the continental United States); (4) the establishment of relay stations to permit 24-hour service on long distance circuits or to avoid a path too close to the magnetic pole ${ }^{18}$ (5) radio trunk lines which will systematize our whole network of point-to-point circuits and thus save precious frequencies; (6) the use of many channels, possibly six to eight, on one frequency; (7) a world system of short wave broadcasting stations on the pattern of the Montreux Plan ${ }^{10}$ (which regulates standard broadcasting in Europe) and the North American Regional Broadcasting Agreement ${ }^{20}$ to eliminate wasteful duplication and further avoid interference; (S) the establishment in the American region of the Inter-American Telecommunications Union which, within the framework of the International Telecommunication Union, will accomplish for the American continents what the International Union does for the whole world; ${ }^{21}$ (9) the centralization and unification of aviation radio services by government agencies such as the Civil Aeronautics Administration and private cooperatives such as Aeronautical Radio, Inc.; and (10) the increase of the services at present performed by Press Wireless, Inc., a newspaper cooperative radio communication service, so that our newspapers and news agencies may place before the American public the greatest volume of news at the least possible cost.

So much for today and tomorrow, but how about the future? IVe shall come to the day when the transmission of intelligence word by word will be as obsolete as the transportation of goods on the back of a mule. In the war recently ended, the necessity of conserving space has brought about the transportation of foods in dehydrated condition. $\mathrm{V}$-mail reduced the bulk of correspondence. In our future world, written messages will be sent by facsimile, and charges will be based on square inches or preferably square millimeters. Under such a system we shall avoid all possibility of errors in transmission and have the satisfaction of receiving the messages as originally sent out. We anticipate the day when, at his breakfast table, every man will find his

18. Such a service has just been inaugurated between New Yorls and Moscow with relays at the International City of Tangier. The two American companies concerned are RCA Communications, Inc., and the Maclay Radio and Telegroph Company, Inc., and they operate the United States terminals as well as the Tangier relay. This teletypawriter service, which constitutes the most modern means of communications, acsures a 24hour service between the United States and the Union of Soviet Socialist Republics. It replaces a similar circuit which was established during the war by the Signal Corps with a relay at Algiers.

19. See Dep't of State Conference Ser. No. 72, International Conference Series, European Broadcasting Conference-1939, Doc. No. 6.

20. North American Regional Broadcasting Agreement between the United States of America, Canada, Cuba, Dominican Republic, Haiti, and Mfexico, signed at Habana, December 13, 1937, U. S. TREATY Ser. No. 962 (1941).

21. See Article by Harvey Boyd Otterman, Assistant Chief, Telecommunications Division, Dep't of State, in Journal of Cosmerce, April 15, 1946, § 2, p. 14A, col. 1. 
favorite newspaper, whether it be from New York, London, Paris, or Rio, on his broadcast receiver in facsimile. The sending of telegrams will consist of placing an original message in a slot-machine and having it reproduced by facsimile in a matter of a few seconds at a distance of hundreds or thousands of miles. There may one day be a universal telecommunication company, with subsidiaries in every country of the world, which will operate all telecommunication services with standard. ized equipment and standardized procedures. Its competition will come from air mail which will eliminate all but urgent telecommunication services. Perhaps a coaxial cable will run from Washington and New York overland through Alaska and the Aleutians to Siberia, Russia. and western Europe, to take a tremendous load of United StatesEurope traffic off the congested radio waves. In this connection, it is incidentally interesting to recall that at one time there existed an overland telegraph line from Great Britain (with a channel submarine cable) to India.

Finally, space will be annihilated, and thought will travel as fast as. the speed of electricity and the ingenuity of man has made possible. Science thus will serve mankind if political organization can keep pace. Statesmen must insure that intelligence may freely cross international boundaries. Freedom of information must be a cornerstone of the new world, so that every man in every country will be free to choose what he wants to see and hear from what men in every other country offer to show and tell him. 